PROCEEDINGS OF THE WORLD CONFERENCE ON OZONE THERAPY IN MEDICINE, DENTISTRY AND VETERINARY. ANCONA (ITALY). SEPTEMBER 22nd - 23rd - 24th, 2017

\title{
DNA analysis of root canal teeth and cavitation surgery of sockets utilizing ozone water irrigation: a pilot study [abstract]
}

John A Rothchild

Dentistry, Durango, Colorado, United States of America

\section{ABSTRACT}

\section{OPEN ACCESS}

\section{Citation}

Rothchild JA. DNA analysis of root canal teeth and cavitation surgery of sockets utilizing ozone water irrigation: a pilot study [abstract]. Proceedings of The World Conference on Ozone Therapy in Medicine, Dentistry and Veterinary. Ancona (Italy). September 22nd - 23rd - 24th , 2017. J Ozone Ther. 2019;3(4):52. doi: 10.7203/ jo3t.3.4.2019.15532

Academic Editor

Jose Baeza-Noci,

School of Medicine, Valencia University, SPAIN

\section{Editor}

World Federation of Ozone Therapy, Bolgna, ITALY

\section{Received}

June 17, 2019

\section{Accepted}

December 08, 2019

Published

December 30, 2019

Intellectual Property

John A Rothchild.

This is an open access article distributed under the terms of the Creative Commons Attribution License (CC BY 4.0), which permits unrestricted use, distribution, and reproduction in any medium, provided the original author and source are credited.

\section{Author Information} jrothchild@aol.com
Purpose. Root canal therapy in dentistry has been the standard of care to save an infected for many years. 1 It has been a premise that once the root canal procedure has been performed, the tooth is free of infection and poses no harm to the patient's health. With the advent of PCR DNA analysis2, root canal teeth and the surrounding bone can be analyzed for toxicity. Current testing can determine 90 plus bacteria and viruses that may be associated with an assay. 9 subjects were selected for this study to determine the toxicity of the root canal tooth that was extracted and if this cavitation protocol decreased bacterial and viral load in the associated bone.

Material and Methods. Each tooth was extracted and sent for analysis. The extraction socket was decorticated and cavitated with a specific protocol using ozonated water as an irrigant. The patients returned approximately one month later for DNA analysis and placed on a Biocidin (an herbal antibiotic) protocol and to return approximately one month later for analysis.

Results. DNA analysis revealed significant bacterial and viral infections of the root canal teeth. After cavitation surgery, the bacterial and viral loads in the bone significantly reduced using the cavitation protocol with ozone water irrigant. The bacterial load seemed to decrease and slightly change with the Biocidin regimen.

Conclusion. Understanding the toxic effects of root canal teeth, and a protocol to remove them properly, this pilot study has shown unequivocally, that this protocol including ozonated water irrigant and an herbal remedy reduced the remaining infection in the bone.

\section{References}

1. Rothchild JA, Harris RE, Mollica PJ. Current concepts of oxygen ozone therapy in the United States. Int Journal Ozone Therap. 2010;9(2):105-108.

2. Valones MA, et al. Principle and application of Polymerase Chain Reaction in medical diagnostic fields: A Review. Braz J Microbiol. 2009;40(1):1-11. doi: 10.1590/S1517-83822009000100001 